\title{
Tank 41H Bounding Uranium Enrichment
}

by

\author{
W. S. Cavin
}

Westinghouse Savannah River Company

Savannah River Site

Aiken, South Carolina 29808

This paper was prepared in connection with work done under the above contract number with the U. S. Department of Energy. By acceptance of this paper, the publisher and/or recipient acknowledges the U.S. Government's right to retain a nonexclusive, royalty-free license in and to any copyright covering this paper, along with the right to reproduce and to authorize others to reproduce all or part of the copyrighted paper. 


\section{DISCLAIMER}

This report was prepared as an account of work sponsored by an agency of the United States Government. Neither the United States Government nor any agency thereof, nor any of their employees, makes any warranty, express or implied, or assumes any legal liability or responsibility for the accuracy, completeness, or usefulness of any information, apparatus, product, or process disclosed, or represents that its use would not infringe privately owned rights. Reference herein to any specific commercial product, process, or service by trade name, trademark, manufacturer, or otherwise does not necessarily constitute or imply its endorsement, recommendation, or favoring by the United States Government or any agency thereof. The views and opinions of authors expressed herein do not necessarily state or reflect those of the United States Government or any agency thereof.

This report has been reproduced directly from the best available copy.

Available to DOE and DOE contractors from the Office of Scientific and Technical Information, P.O. Box 62, Oak Ridge, TN 37831; prices available from (615) 576-8401.

Available to the public from the National Technical Information Service, U.S. Department of Commerce, 5285 Port Royal Road, Springfield, VA 22161. 


\section{DISCLAIMER}

Portions of this document may be illegible in electronic image products. Images are produced from the best available original document. 
Chemical Process Technology Department

Chemical and Hydrogen Technology Section

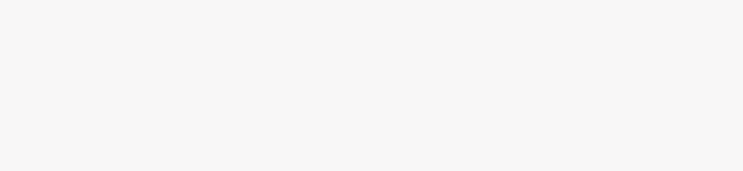

Tank 41H Bounding Uranium Enrichment (U)

By W. S. Cavin

Issued: September 30, 1994
WSRC-TR-94-0224

Revision: 1

Keywords:

Wastes

Waste Tanks

Criticality Safety

Enriched Uranium

Retention:

Permanent

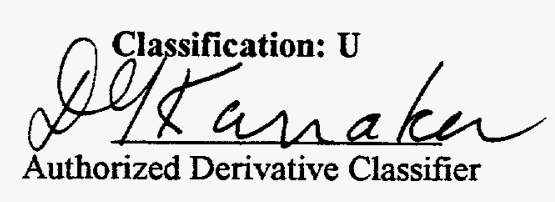

Date: $\quad 9 / 30 / 94$

Date: $10 / 6 / 94$

Date: $9-30 \cdot 94$

Date: $9-30 \ldots i 4$

D. G. Karraker, Technical Reviewer (2).K $/ 2$

D. T. Hobbs, Technical Reviewer 


\section{Introduction}

The intent of this document is to combine data from salt samples and historical process information to bound the uranium (U-235) enrichment which could be expected in the upper portion of the salt in Tank $41 \mathrm{H}$. This bounding enrichment will be used in another document ${ }^{1}$ to establish a nuclear safety basis for initial salt removal operations.

\section{Sample Background}

Two series of samples have been taken at the surface of the salt in Tank $41 \mathrm{H}$. The first sample was a $1.5^{\prime \prime}$ core and the second set of 3 samples were taken from the same hole to a total depth of 12". The two sets of samples were from risers $180^{\circ}$ apart in an attempt to quantify any lateral inhomogeneities which may exist in the tank. Table 1 summarizes pertinent data from these two sets of samples 13,14 .

Table 1

\begin{tabular}{|c|c|c|c|c|c|}
\hline Sample\#* & $\begin{array}{l}\text { U conc. in } \\
\text { Salt (ug/g) }\end{array}$ & $\begin{array}{l}\text { Soluble U } \\
\text { in Salt }(\%)\end{array}$ & $\begin{array}{l}\text { U-235 } \\
\text { Enrichment (\%)*** }\end{array}$ & $\begin{array}{l}\text { Interstitial } \\
\text { Liquid (vol\%) }\end{array}$ & $\begin{array}{l}\text { Density } \\
\text { of } \operatorname{Salt}(\mathrm{g} / \mathrm{mL}\end{array}$ \\
\hline$\# 1-1$ & 5.1 & 89 & 15.6 & $\overline{32}$ & $\overline{1.9}$ \\
\hline$\# 2-1$ & 4.7 & 82 & 16.2 & 26 & $* * * *$ \\
\hline$\# 2-3$ & 2.3 & 64 & 14.8 & 25 & $* * * *$ \\
\hline
\end{tabular}

* Sample \#1-1 is the first 1.5" core. Samples \#2-1 and \#2-3 are from the second series of samples taken on the other side of Tank 41H. Sample \#2-1 was taken from the surface (first sample in that hole) and \#2-2 and \#2-3 were the numbers of the next two samples. No data was included in Table 1 for sample \#22 because there was only a small amount of sample so limited analyses were done.

** The values listed are the $95 \%$ confidence minimum (avg. minus 2 times std. dev.) values for this data point.

*** The values listed are the $95 \%$ confidence maximum values for this data point.

**** Density values were calculated for the samples in the second set, but it is believed that these calculated values were in error due to analytical procedure. The actual value should be around $1.9 \mathrm{~g} / \mathrm{mL}$ which was determined for the first sample.

The data of primary interest to this discussion is the U-235 enrichment and the concentration of uranium in the interstitial liquid in the salt sample. The interstitial liquid characteristics at the salt surface should give a good indication of what the uranium enrichment and concentration of the $2 \mathrm{H}$ Evaporator bottoms were when the final batch of evaporator bottoms were transferred to Tank $41 \mathrm{H}$. Conclusions about the uranium enrichment and concentration in the final evaporator bottoms can then be used to make assumptions about the enrichment of uranium deeper into the salt cake. In the discussions which will follow, it is conservative to assume a lower uranium concentration and a higher uranium enrichment in the salt cake surface interstitial liquid. It is for this reason (conservatism) that some of the values reported in Table 1 have been given at upper and some at lower $95 \%$ confidence intervals.

The interstitial liquid uranium concentration and enrichment at the surface of the salt will be estimated in the following way. For the two surface samples (\#1-1 and \#2-1) the lower 95\% confidence interval total salt uranium concentrations were multiplied by the salt density (assumed to be $1.9 \mathrm{~g} / \mathrm{mL}$ ) and the fraction of the total uranium which was soluble in inhibited water. This value was divided by the volume fraction 
of the salt which consisted of interstitial liquid to give the estimated interstitial uranium concentration. The results of these calculations was an estimated concentration of $27 \mathrm{mg} / \mathrm{L}$ for sample \#1-1 and $28 \mathrm{mg} / \mathrm{L}$ for sample \#2-1.

This method of estimating the interstitial liquid concentration would be biased high if there were uranium solids in the salt samples which dissolved when the inhibited water was added. In this case, the uranium concentration in the interstitial liquid could be much lower than estimated using the above calculation, because most of the uranium would have come from dissolved solids instead of diluted interstitial liquid. There are two reasons why it is unlikely that a significant bias due to uranium solids would appear in the interstitial concentration estimates made from Tank $41 \mathrm{H}$ sample results. First, the estimated uranium concentrations are within the range of expected uranium solubility under these conditions. H-Area waste tank samples have shown uranium concentrations up to $20 \mathrm{mg} / \mathrm{L}^{5}$ and evaporation tests with simulated low heat waste, concentrated uranium to over $30 \mathrm{mg} / \mathrm{L}^{15}$. Uranium solubility is still not well understood, but based on what is known, it is not unreasonable to assume that a uranium concentration of $27 \mathrm{mg} / \mathrm{L}$ is below the saturation point at these conditions. The second point to consider is whether any uranium solids that had been present would have gone back into solution in the inhibited water. A recent study 16 indicates that the precipitation of uranium solids is largely irreversible. In this study, precipitated uranium was only soluble toward redissolution to a concentration of $2-5 \mathrm{mg} / \mathrm{L}$. If this is correct, then any solid uranium in the Tank $41 \mathrm{H}$ salt samples would have had little effect on the total salt uranium concentration after dissolution of the salt cake. For these reasons, neglecting the contribution of uranium precipitates when estimating the interstitial liquid uranium composition is considered justifiable. In the discussion that follows, it will be assumed that the uranium composition in interstitial supernate at the salt surface is $27 \mathrm{mg} / \mathrm{L}$ with a U-235 enrichment of $16 \%$.

\section{General Background}

During the processing period of interest (4/82-4/87), waste was fed to the $2 \mathrm{H}$ Evaporator from Tank $43 \mathrm{H}$, and the evaporator bottoms were sent to Tank $41 \mathrm{H}$ where the bottoms were allowed to cool (resulting in the formation of salt deposits in the tank). As Tank $41 \mathrm{H}$ was filled with concentrate, the supernate left after salt formation was recycled back to Tank $43 \mathrm{H}$ and reprocessed through the evaporator along with any additional waste which had been added to Tank $43 \mathrm{H}$. As Tank $41 \mathrm{H}$ filled with salt, this recycle took place with increasing frequency because it took less time to fill the decreased volume with evaporator concentrate.

The uranium that enters waste evaporation systems is primarily that portion of the uranium in the liquid waste stream from the separations canyons which remains soluble when the acidic waste is neutralized in the canyons. The majority of the uranium in canyon wastes is precipitated in the canyon waste neutralization process, and becomes a part of the insoluble (sludge) portion of the waste stream. Very little data is available on the concentration of soluble uranium in canyon waste streams. The only data of this type which is available, comes from two reports 2,3 which document a comprehensive study of waste tank supernate composition conducted in the mid-1970s. By determining which of the sampled waste tanks were receiving fresh waste from the canyons at the time the tanks were sampled (from published transfer records ${ }^{4}$ ), it was possible to deduce which samples were likely representative of fresh canyon waste. The processing that was being carried out in the separation process canyons when these tanks were sampled, should be comparable to the processing while Tank $41 \mathrm{H}$ was being filled. Table 2 shows the available fresh waste uranium concentration data. 
WSRC-TR-94-0224

Revision 1

Table 2

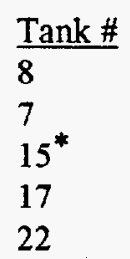

Waste Stream
F - High Heat Waste
H - High Heat Waste
H - High Heat Waste
F - Low Heat Waste
H - Low Heat Waste

\begin{tabular}{c} 
U Concentration (mg/1) \\
\hline 13 \\
0.5 \\
2 \\
3.1 \\
0.5
\end{tabular}

* Two tanks were determined to contain fresh high heat waste from $\mathrm{H}$-Canyon because the tank transfer records indicate that while tank 15 was not the active fresh waste receiver when the samples were taken, it was the fresh waste receiver 10 months earlier and had been undisturbed since that time.

The fresh canyon waste is evaporated in one of the waste evaporation systems to decrease the volume. Evaporation of these solutions leads to a corresponding increase in the uranium concentration of the waste supernate. The limited data that is available indicates that the uranium concentration around the waste evaporator systems can increase significantly as the dilute uranium-containing solutions are evaporated and recycled back through the evaporator multiple times. Uranium concentrations as high as $56 \mathrm{mg} / \mathrm{L}$ in F-Area wastes, and $20 \mathrm{mg} / \mathrm{L}$ in H-Area wastes 5 have been observed in samples around waste evaporator systems. This concentration mechanism helps explain how salt (in Tank $41 \mathrm{H}$ ) formed from H-Canyon low heat waste that is expected to have a very low uranium concentration, could have supernate entrained in the upper layer with a concentration of $27 \mathrm{mg} / \mathrm{L}$. It has also been demonstrated 15 that as uranium concentrations increase during evaporation, the solubility of uranium is exceeded and uranium precipitation occurs. It is primarily this scenario that has led to the nuclear criticality safety evaluation for the redissolving of the salt in Tank $41 \mathrm{H}$.

\section{Discussion}

As the salt in Tank $41 \mathrm{H}$ is dissolved, one of the variables which will affect the nuclear criticality safety of the operation, is the U-235 enrichment of the uranium in the salt. This is the case because uranium with a higher percentage of the fissile U-235 isotope requires a smaller total mass of uranium to achieve a critical mass. The establishment of an upper bounding enrichment for a given salt dissolution batch may allow for calculations demonstrating that the operation is safe even under worst-case circumstances. The approach that will be used to bound the uranium enrichment in the uppermost part of the salt in Tank $41 \mathrm{H}$ involves using a combination of salt sample results and historical evaporator and tank transfer data.

As mentioned previously, sample results are available which give information on the uranium enrichment and concentration at the upper surface of the salt. Since the tank has been largely undisturbed since it was filled with salt, the enrichment and concentration values from the interstitial supernate in the surface samples are believed to be representative of the last evaporator bottoms which were fed to Tank $41 \mathrm{H}$. The only activity which has occurred in Tank $41 \mathrm{H}$ since it was filled with salt has been the addition of relatively small amounts of water and several transfers of supernate from the tank. These water additions could possibly have diluted the uranium concentration of the supernate in the salt matrix, but any dilution which took place would not affect the uranium enrichment. Any dilution of uranium concentration which may have taken place in the interstitial supernate, would result in added conservatism in determining a bounding enrichment for the upper portion of the salt (as demonstrated later in this report). If the assumption is maintained that the uranium concentration in the salt samples from the surface is representative of the final evaporator bottoms, some conclusions about the salt below the surface can be drawn.

According to $2 \mathrm{H}$ Evaporator operating data ${ }^{6}$, the final $213 \mathrm{kgal}$ of tank 41 salt was formed in the last $\sim 1.5$ months of the tank 41 fill period. Since this last layer $(\sim 5 \mathrm{ft}$ assuming $3510 \mathrm{gal} / \mathrm{inch})$ of salt was formed 
so quickly, it seems unlikely that the prevailing uranium enrichment around the evaporator system would have decreased significantly during this short time span. The uranium enrichment around the $2 \mathrm{H}$ Evaporator is believed to have gradually decreased during the Tank $41 \mathrm{H}$ fill period. This assumption is based on the fact that about 3.5 million gallons of waste supernate from the 1982 Extended Sludge Processing (ESP) demonstration was transferred to the $2 \mathrm{H}$ Evaporator system only a few months after tank 41 went into use as the bottoms receiver. This ESP supernate was sampled for uranium and was found to contain a total of $28 \mathrm{~kg}$ of total soluble uranium with uranium concentrations from 0.2 to $12.8 \mathrm{mg} / \mathrm{L}^{7}$. The sludge that was washed in the ESP demo came from Tank $15 \mathrm{H}$ and is estimated to contain uranium with a bulk enrichment of $71 \% 8$. From this information it can be concluded that from the initial introduction of a large quantity of highly enriched uranium to the evaporator in 1982, until Tank $41 \mathrm{H}$ was filled in 1987, the uranium enrichment was diluted from $70 \%$ to around $15 \%$ (the sample result from the surface of the salt). This enrichment dilution is not surprising since the enrichment of the uranium discarded to waste from the (H-Canyon) HM Process after the ESP transfer was much lower due to Low Enriched Uranium campaigns and the uranium recycle program. Large volumes of supernate were also transferred to the $2 \mathrm{H}$ Evaporator from the transfer and washing of (F-Area) depleted uranium sludges $(-0.3 w t \% \mathrm{U}-235)$. In other words, the enrichment of the uranium in Tank $41 \mathrm{H}$ is expected to be higher at the bottom of the tank than at the top. The question at hand is how much could it reasonably have decreased during the last 1.5 month of salt deposition?

To answer the question of how much the enrichment could reasonably have decreased as the last 5 feet of salt was made, it is necessary to make some assumptions about what was fed to the evaporator during this final period. In order to do this, an additional assumption will be made that when waste supernate is added to a tank, it will form layers which remain intact until that particular waste layer is transferred to another tank or an evaporator. This assumption is rather simplistic considering the complex mixing patterns that certainly exist in tanks as large as the SRS waste tanks $(\sim 1.3$ million gallons). In certain circumstances this assumption will not be valid (i.e. when high density supernate is added to a tank containing low density waste), but in other circumstances it should fairly accurately reflect what actually happened (when incoming waste has equal or lesser density). Though the layering assumption was used to determine what types of waste were being transferred at different times, an effort was made to evaluate these conclusions in light of variables (density differences and transfer volumes) which may have caused deviation from layering behavior.

The effect of temperature on waste density was not taken into account in this analysis. The qualitative density differences which are used in this report to create mixing scenarios should be at least two tenths of a specific gravity unit. The temperature differences which may be seen in the waste tanks should result in density changes of less than one tenth of a specific gravity unit (Appendix A). It is for this reason, that any density differences resulting from temperature are considered negligible.

The assumption of perfect layering in Tank $43 \mathrm{H}$ (evaporator feed tank) was used, and a volume balance was made (using historical waste transfer and receipt data ${ }^{10}$ ) during the time the evaporator produced the bottoms which were cooled to produce the last 5 feet of salt. Table 3 estimates the waste solutions which were fed to the evaporator during this 1.5 month period using the method described above. A sample volume balance calculation appears in Appendix B.

Table 3

\begin{tabular}{lcc} 
Waste Type & Volume (kgal) & \% of Total Volume \\
\cline { 2 - 3 } Recycle from Tank 41H & 845 & 77 \\
Waste from Tank 51H & 131 & 12 \\
Waste From Tank 42H & 66 & 6 \\
Fresh H-Low Heat Waste & 54 & 5
\end{tabular}

The Tank 43H composition shown in Table 3 is typical of the ratios and types of feed which were sent to the evaporator during this period. The actual content of the feed during this period may have differed 
somewhat due to deviation from perfect layering behavior. However, because waste that was transferred into Tank $43 \mathrm{H}$ shortly before and after the solutions shown in Table 3 were from the same tanks and in approximately the same ratios, any variations from perfect layering are not expected to introduce significant error.

A key element in this discussion will be the nature of the waste solutions which were mixed with the recycle and evaporated to form the last 5 feet of salt. This is true because if the feed during the formation of the last 5 feet of salt had been $100 \%$ recycle, then the uranium enrichment in this portion of the salt could reasonably be expected to be constant. Therefore, the central question is whether the solutions that were mixed with the recycle from Tank $41 \mathrm{H}$ could have significantly altered the bulk uranium enrichment around the evaporator during this short time span. In order to pursue this question, it was necessary to research the nature of the waste solutions that were mixed with the recycle during this period. The following sections summarize the results of this research and contain conservatively estimated waste stream characteristics.

\section{Tank 51H Waste}

From a volume balance (assuming perfect layering), the waste from Tank $51 \mathrm{H}$ to Tank $43 \mathrm{H}$ is assumed to be from the first Tank $22 \mathrm{H}$ salt dissolution batch . Based on the history of Tank $51 \mathrm{H}$, the assumption of perfect layering seems to be reasonable. Tank $51 \mathrm{H}$ was put into service in $6 / 86$ and initially contained 67 $\mathrm{kgal}$ of flush water. In $7 / 86,300 \mathrm{kgal}$ of waste from the first Tank $18 \mathrm{~F}$ sludge slurry was added to Tank $51 \mathrm{H}$. The first Tank $18 \mathrm{~F}$ sludge slurry was done with waste from the first Tank $20 \mathrm{~F}$ salt dissolution batch, so this waste would have had a high specific gravity (saturated with salt) and would have mixed with the small amount of flush water already in the tank. A week later, $352 \mathrm{kgal}$ of waste from the first Tank $22 \mathrm{H}$ salt dissolution batch was added to Tank $51 \mathrm{H}$ on top of the flush water and Tank $18 \mathrm{~F}$ waste. The salt removal waste from Tank $22 \mathrm{H}$ would have been saturated with salt and should have had a density similar to that of the waste from Tank $18 \mathrm{~F}$. Because the densities were similar, there should not have been significant mixing when the Tank 22 waste was added to Tank $51 \mathrm{H}$. About a month later, waste from the second Tank $18 \mathrm{~F}$ sludge removal batch was added to Tank $51 \mathrm{H}$. This batch was also slurried with Tank $20 \mathrm{~F}$ salt removal waste and would not be expected to mix appreciably with the layer below (Tank $22 \mathrm{H}$ waste) because it had a density in the same range as the waste already in the tank. The subsequent waste additions were either comparable or more dilute than the waste in Tank $51 \mathrm{H}$ leading to the conclusion that the tank was layered to a large degree.

Tank $22 \mathrm{H}$ became a Low Heat Waste (LHW) tank in 1974. Prior to that time, Tank $22 \mathrm{H}$ was used as a receiver of High Heat Waste (HHW) evaporator concentrate. Before the tank was converted to LHW service, all but about $58 \mathrm{kgal}$ of the HHW salt was removed. From $7 / 74$ to $4 / 76$, Tank $22 \mathrm{H}$ received fresh Low Heat Waste (H-LHW) from H-Canyon. At the end of this period, the fresh H-LHW in Tank $22 \mathrm{H}$ was transferred to Tank $21 \mathrm{H}$ as feed for the $242-\mathrm{H}$ Evaporator. Tank $22 \mathrm{H}$ was then used as the concentrate receiver for the volume reduction of this H-LHW material. The final Tank $22 \mathrm{H}$ salt level was about 130 $\mathrm{kgal}$, so about $72 \mathrm{kgal}$ of LHW salt was formed on top of the $58 \mathrm{kgal}$ of HHW salt which remained in the tank after the previous salt removal. The first Tank $22 \mathrm{H}$ salt removal batch in $7 / 86$ was reported to have contained $58 \mathrm{kgal}$ of salt, so it is reasonable to conclude that the first batch material contained predominantly LHW salt from the $1976 \mathrm{H}-\mathrm{LHW}$ evaporation. H-Canyon waste uranium losses indicate that the combined U-235 enrichment of the H-LHW which was used to form this salt (7/74-4/76 discards) was $7 \% 9$. The uranium concentration of the $\mathrm{H}-\mathrm{LHW}$ which was volume-reduced and sent to Tank $22 \mathrm{H}$ during this period was likely higher than normal due to above average uranium losses from H-Canyon. However, the uranium in the bottoms sent to Tank $22 \mathrm{H}$ to form the upper layer of salt would not have had the opportunity to concentrate to an extremely high level because the salt was formed in Tank $22 \mathrm{H}$ after only one pass through the evaporator (no recycle). The uranium concentration of the evaporator bottoms that resulted in the formation of the upper layer of Tank $22 \mathrm{H}$ salt will be estimated at $27 \mathrm{mg} / \mathrm{L}$. The 27 $\mathrm{mg} / \mathrm{L}$ is a conservative estimate based on the supernate uranium concentration that was determined from the Tank $41 \mathrm{H}$ samples. This result was the highest ever observed for H-Area wastes. The highest (routine) supernate sample result that has been observed for concentrated H-Area supernate solutions is 20 
$\mathrm{mg} / \mathrm{L}^{5}$. If the uranium concentration in the interstitial supernate is assumed to be $27 \mathrm{mg} / \mathrm{L}$ and the salt is assumed to have $50 \mathrm{vol} \%$ interstitial supernate 11 and a water/salt dissolution ratio of $1.0^{12}$, the concentration of uranium in the Tank $22 \mathrm{H}$ salt dissolution waste would have been $7 \mathrm{mg} / \mathrm{L}$. Based on the preceding information, the waste from the first Tank $22 \mathrm{H}$ salt dissolution batch will be assumed to have contained uranium at a concentration of $10 \mathrm{mg} / \mathrm{L}$ with an enrichment of $5 \%$.

Tank 42 Waste

The first transfer ( $11 \mathrm{kgal}$ ) from Tank $42 \mathrm{H}$ to Tank $43 \mathrm{H}$ is expected to have consisted primarily of material from the first Tank $21 \mathrm{H}$ sludge removal batch (from a volume balance; assuming perfect layering). The assumption of perfect layering should be reasonable in this case based on the types of waste which were added to Tank $42 \mathrm{H}$. Tank $42 \mathrm{H}$ was only about a third full when waste from the fourth Tank $18 \mathrm{~F}$ sludge removal batch was added. The fourth Tank $18 \mathrm{~F}$ batch was slurried with Tank $20 \mathrm{~F}$ salt removal waste and should have had a high density because of salt saturation. Three days later, waste from the first Tank $21 \mathrm{H}$ sludge removal batch was added on top of the Tank $18 \mathrm{~F}$ batch four waste. Significant mixing would not be expected because Tank $21 \mathrm{H}$ was slurried with waste from the RBOF facility (essentially water) and should have had a much lower density than the saturated salt solution below. Three days later, waste from the fifth Tank $18 \mathrm{~F}$ sludge removal batch was added to Tank $42 \mathrm{H}$. This waste could be expected to have a density which was comparable to the Tank $21 \mathrm{H}$ slurry waste below, because starting with the fifth batch, the remaining Tank $18 \mathrm{~F}$ sludge slurry batches were slurried with inhibited water. Subsequent transfers to Tank $42 \mathrm{H}$ consisted of either Tank $21 \mathrm{H}(1$ transfer) or Tank 18F (3 transfers) sludge slurry waste which should have all had similar (low) densities and provided minimal mixing.

As mentioned previously, sludge was removed from Tank $21 \mathrm{H}$ by slurrying the tank with RBOF waste. Tank $21 \mathrm{H}$ contained about $100 \mathrm{kgal}$ of sludge which was deposited in the early $60 \mathrm{~s}$ and the rest $(\sim 113$ $\mathrm{kgal}$ ) was sludge from the receipt of fresh H-LHW between 1976 and 1981. According to canyon uranium loss data, during the deposition of the later sludge layer (1976-1981), the U-235 enrichment should be about $38 \% 9$. The earlier sludge layer was deposited primarily from the receipt of Tank $14 \mathrm{H}$ sludge removal solution. According to tank history records, Tank $14 \mathrm{H}$ received most of its sludge from $\mathrm{H}$ Canyon PUREX waste which would have contained depleted uranium. Since the presence of PUREX sludge should drastically decrease the overall enrichment of mixed PUREX/HM sludges $(\sim 1,000$ times more $U$ in PUREX sludges), the U-235 enrichment of the Tank $21 \mathrm{H}$ sludge removal solution should have been around $1 \%$. The uranium concentration of the Tank $21 \mathrm{H}$ sludge removal solution is expected to have been relatively high. This solution would have been in intimate contact with PUREX sludge which contains a large amount of uranium. Though the uranium in the PUREX sludge is not expected to be highly soluble, a conservative uranium concentration for the sludge wash supernate of $30 \mathrm{mg} / \mathrm{L}$ will be assumed.

The other Tank $42 \mathrm{H}$ to Tank $43 \mathrm{H}$ transfer ( $55 \mathrm{~K} \mathrm{gal}$.) is expected to have contained material from the fifth Tank $18 \mathrm{~F}$ sludge removal batch. The fifth Tank $18 \mathrm{~F}$ batch is expected to have contained depleted uranium with a uranium concentration that is relatively low. The uranium concentration is expected to have been low because most of the soluble uranium should have been washed from the sludge before the fifth batch. Since inhibited water was used to slurry this (5th) batch, there would be no soluble uranium contribution from the slurry solution like there probably was when the Tank $20 \mathrm{~F}$ salt removal solution was used to slurry Tank 18F (1st four batches). The U-235 enrichment of the wash water will be assumed to be $0.2 \%$ and the $U$ concentration conservatively assumed to be $10 \mathrm{mg} / \mathrm{L}$.

\section{Fresh H-Low Heat Waste}

The uranium in the fresh $\mathrm{H}$-Canyon waste that was discarded to Tank $43 \mathrm{H}$ during this period is estimated to have an enrichment of $55 \%$. Since the uranium concentration in fresh H-LHW is known to be low (see Table 2), and the enrichment was high, the uranium concentration of this waste will be conservatively assumed to be zero. This assumption is conservative because if the fresh waste did contain uranium at a 
high enrichment, it would have helped to move the enrichment of the uranium around the $2 \mathrm{H}$ system higher instead of lower.

\section{Evaporation/Mixing Scenario}

A bounding uranium enrichment of $22 \%$ in the top five feet of salt will be defended in the following scenario. This discussion will call on previously presented information as well as additional assumptions.

From a volume balance in Tank $43 \mathrm{H}$, a mixture of Tank $41 \mathrm{H}$ recycle and fresh waste that were added to Tank 43H during January 1987, was being fed to the evaporator when the last five feet of salt began to form on $3 / 1 / 87$. According to transfer records, only fresh waste and recycle material were transferred to Tank $43 \mathrm{H}$ during January, so this waste is assumed to have a constant uranium enrichment and concentration. In this mixing scenario, this material can be thought of as the first layer of waste that was evaporated to form the last five feet of salt, so it will be referred to as Layer 1 (L1). The material in L1 is assumed to have a uranium enrichment of $22 \%$. This percentage was assumed because $22 \%$ is the enrichment which will be defended as the highest possible enrichment that could be encountered in the top five feet of salt (the highest enrichment would be expected at the bottom of the top five feet). The uranium concentration in the $\mathrm{L} 1$ material was assumed to be $16 \mathrm{mg} / \mathrm{L}$. This value was calculated by assuming that the evaporator bottoms from the $\mathrm{Ll}$ material have a uranium concentration of $22 \mathrm{mg} / \mathrm{L}$ after a volume reduction of 1.4 (typical value from evaporator operating data). The $22 \mathrm{mg} / \mathrm{L}$ was arrived at by making the final evaporator bottoms uranium concentration of $27 \mathrm{mg} / \mathrm{L}$ (from the Tank $41 \mathrm{H}$ salt samples) more conservative. A schematic diagram of the postulated tank layering on the day that the last five feet of salt began to form (3/1/87), appears in Figure 1.

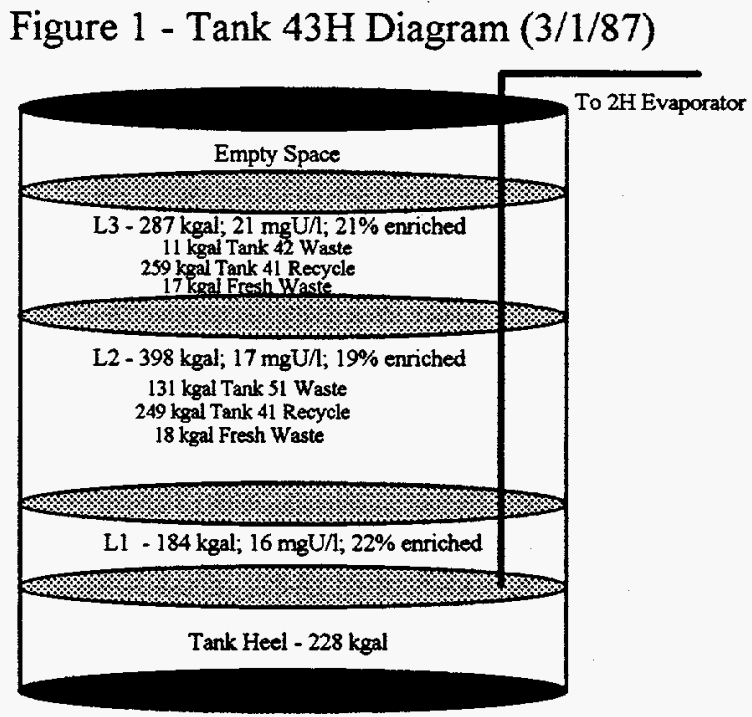

By $2 / 3 / 87,131 \mathrm{kgal}$ of waste from Tank $51 \mathrm{H}$ had been added to Tank $43 \mathrm{H}$ on top of the $\mathrm{L} 1$ material. This Tank $51 \mathrm{H}$ waste is not assumed to mix with the $\mathrm{L} 1$ material, because the Tank $51 \mathrm{H}$ material should be somewhat less dense (due to jet dilution). By $2 / 15 / 87,249 \mathrm{kgal}$ of recycle material and $18 \mathrm{kgal}$ of H-LHW had been added to Tank $43 \mathrm{H}$. This material is assumed to be more dense than the Tank $51 \mathrm{H}$ waste and mix completely with it forming a layer which will be referred to as $L 2$. Using the uranium contents discussed earlier for each stream (no U in H-LHW, $10 \mathrm{mg} / \mathrm{L}$ and $5 \% \mathrm{U}-235$ for tank 51 , and $22 \mathrm{mg} / \mathrm{L}$ and $22 \% \mathrm{U}-235$ for $\mathrm{L} 1$ recycle) the uranium content of the $\mathrm{L} 2$ material is calculated to be $17 \mathrm{mg} / \mathrm{L}$ and $19 \%$ enriched (a sample calculation for thsi mixture appears in Appendix C). Figure 2 shows a schematic diagram of this mixing scenario at the point when the L2 material was just beginning to be fed to the evaporator. 
Figure 2 - Tank 43H Diagram (3/10/87)

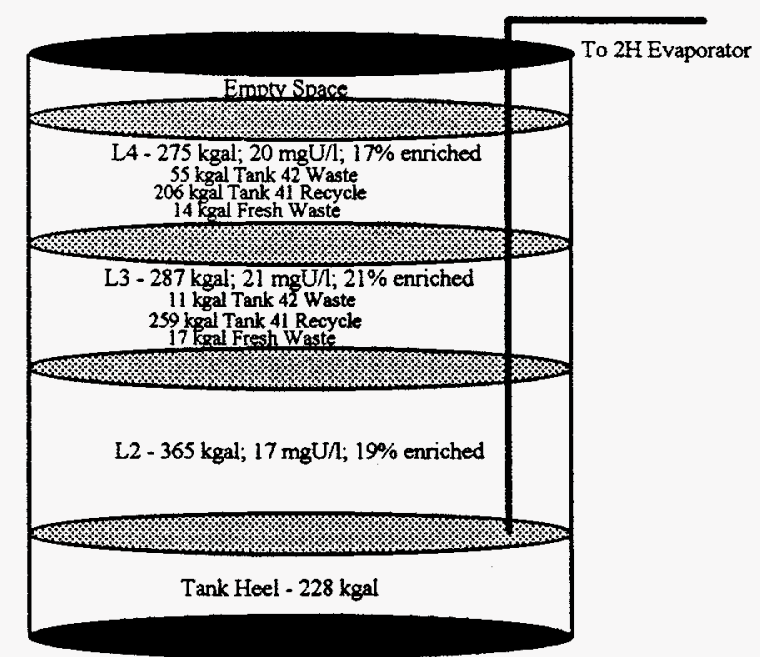

On $2 / 20 / 87,11 \mathrm{kgal}$ of waste from Tank $42 \mathrm{H}$ was added to Tank $43 \mathrm{H}$ on top of the $\mathrm{L} 2$ material. This Tank $42 \mathrm{H}$ waste is not assumed to mix with the $\mathrm{L} 2$ material, because the Tank $42 \mathrm{H}$ material should be significantly less dense (the waste added is estimated to be sludge slurry supernate, which should not be saturated with salt). By $2 / 28 / 87,259 \mathrm{kgal}$ of (L1) recycle material and $17 \mathrm{kgal}$ of $\mathrm{H}-\mathrm{LHW}$ had been added to Tank $43 \mathrm{H}$. This material is assumed to be more dense than the Tank $42 \mathrm{H}$ waste and mix completely with it forming a layer which will be referred to as L3. Using the uranium contents discussed earlier for each stream (no U in H-LHW, $30 \mathrm{mg} / \mathrm{L}$ and $1 \% \mathrm{U}-235$ for tank 42 , and $22 \mathrm{mg} / \mathrm{L}$ and $22 \% \mathrm{U}-235$ for $\mathrm{L} 1$ recycle) the uranium content of the $\mathrm{L} 3$ material is calculated to be $21 \mathrm{mg} / \mathrm{L}$ and $21 \%$ enriched. Figure 3 shows a schematic of the mixing scenario when about half of $L 3$ has been fed to the evaporator.

Figure 3 - Tank 43H Diagram (3/31/87)

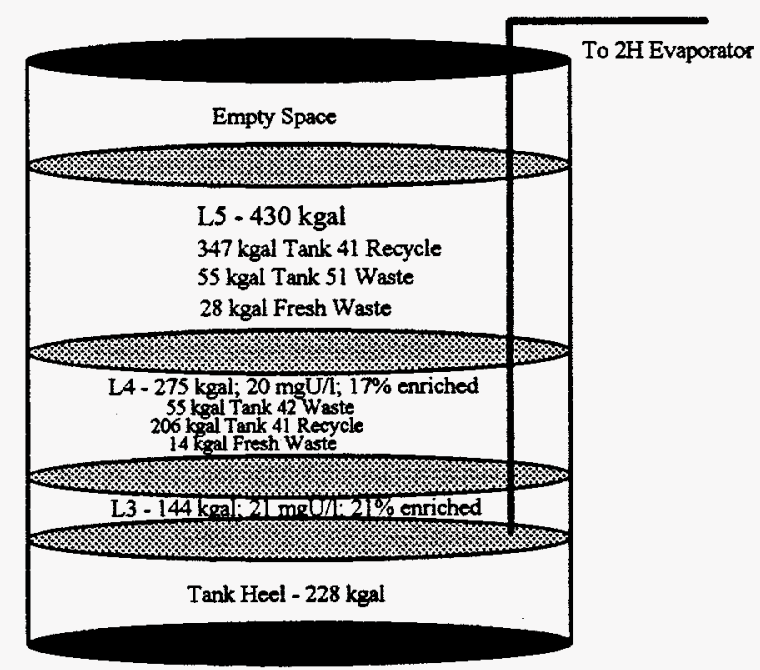

On $3 / 3 / 87,55 \mathrm{kgal}$ of waste from Tank $42 \mathrm{H}$ was added to Tank $43 \mathrm{H}$ on top of the $\mathrm{L} 3$ material. This Tank $42 \mathrm{H}$ waste is not assumed to mix with the $\mathrm{L} 3$ material, because the Tank $42 \mathrm{H}$ material is estimated to be 
sludge slurry waste which should be significantly less dense. By $3 / 10 / 87,206 \mathrm{kgal}$ of recycle material and $14 \mathrm{kgal}$ of $\mathrm{H}-\mathrm{LHW}$ had been added to Tank $43 \mathrm{H}$. This material is assumed to be more dense than the Tank $42 \mathrm{H}$ waste and mix completely with it forming a layer which will be referred to as $\mathrm{L} 4$. Using the uranium contents discussed earlier for each stream (no U in H-LHW, $10 \mathrm{mg} / \mathrm{L}$ and $0.2 \%$ U-235 for Tank $42 \mathrm{H}$, and $24 \mathrm{mg} / \mathrm{L}$ and $19 \% \mathrm{U}-235$ for $\mathrm{L} 2$ recycle) the uranium content of the $\mathrm{L} 4$ material is calculated to be $20 \mathrm{mg} / \mathrm{L}$ and $17 \%$ enriched. A volume balance indicates that $80 \%$ of the recycled bottoms which formed the L4 material was from evaporated L1, but for added conservatism the recycle was assumed to be all evaporated L2 material. Figure 4 shows a schematic of the mixing scenario at the point when the evaporator was shut down (the end of the period when Tank $41 \mathrm{H}$ was used as the bottoms tank).

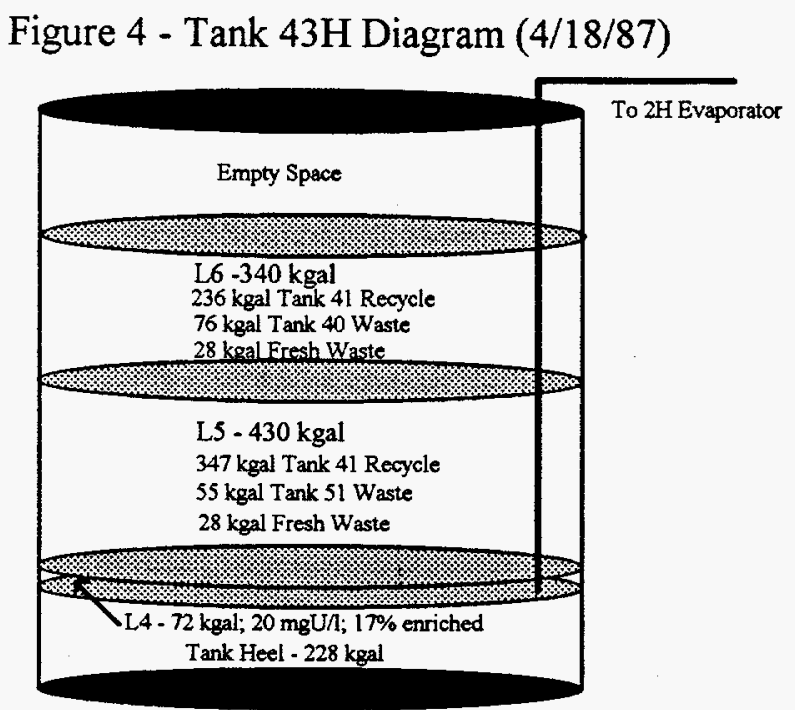

\section{Conclusions}

Any number of mixing scenarios could have been examined for the components which fed the evaporator during the formation of the last five feet of salt. The scenario presented above was designed to be conservative, while still incorporating process knowledge and available data where possible. In the preceding scenario, the lowest enrichment seen in any feed material was for the L4 feed which was evaporated to form the top part of the salt in Tank $41 \mathrm{H}$. The lowest enrichment of $17 \%$ is still higher than the $16 \%$ (95\% confidence) maximum enrichment actually found at the salt surface (from sample results). This leads to the conclusion that the uranium enrichment of the material (L1) which was being fed to the evaporator when the last five feet began to form, was lower than $22 \%$. The conservatism used in this analysis, combined with the available sample data are believed to provide a defensible basis for establishing an upper bounding enrichment of $22 \%$ for the top five feet of salt.

\section{References}

1. J. S. Clemmons. Nuclear Criticality Safety Evaluation of Initiating Tank 41 Salt Removal. WSRC-TR-94-251, Draft Document.

2. R. S. Ondrejcin. Composition and Corrosiveness of Low-Activity Waste Supernates Stored at the Savannah River Plant. USAEC Report DP-1427, E. I. du Pont de Nemours and Company, Savannah River Laboratory, Aiken, SC (1976), Tables B-1 and B-2, p. 15 and 16. 
3. R. S. Ondrejcin. Chemical Compositions of Supernates Stored in SRP High Level Waste Tanks. USAEC Report DP-1347, E. I. du Pont de Nemours and Company, Savannah River Laboratory, Aiken, SC (1974), p. 19 and 21.

4. W. S. Cavin and A. T. Crumm. Fresh Waste Receipts. WSRC-TR-93-426, Rev 0.

5. From unpublished waste tank sample analysis results. A total uranium concentration of 55.8 $\mathrm{mg} \mathrm{U} / 1$ was reported for a $2 / 26 / 92$ tank 26 sample. Tank 26 is the feed tank for the $242-16 \mathrm{~F}$ evaporator and, as such, regularly receives evaporator concentrate recycle. A total uranium concentration of $20.1 \mathrm{mg}$ U// was reported for a 5/16/92 tank 43 sample. Tank 43 is the feed tank for the $2 \mathrm{H}$ evaporator.

6. Evaporator operating data (including tank 41 salt level) was published in monthly reports. The reports from 1985-1988 did not have a document number, but were stored as "WMT Monthly Data Report".

7. Sample results and volumes from: R. E. Eibling and B. A. Hamm. Demonstration of In-Tank Sludge Processing Part IV: Decanted Supernate Composition. DPST-84-798, Tables I-V, (1984).

8. W. S. Cavin. Estimated Waste Tank Sludge Contents. SRT-CTS-93-0253, (1993).

9. The mass and enrichment of uranium in waste sludges was taken from estimates in the Separations Waste Sludge Spreadsheet (WSRC-TR-93-135, Revision 1, July 28, 1993). This information was combined with data on fresh waste receipts and sludge transfers (Reference 10) to calculate an estimated bulk sludge uranium enrichment.

10. The total volume to the $2 \mathrm{H}$ system and the volumes of the various other categories of feeds were determined using waste receipt and transfer data compiled from the Works Technical and Waste Management Monthly Reports. The compilation of fresh waste receipt data has been published as Fresh Waste Receipts, WSRC-TR-93-426, Rev. 0, and the transfer data has been published as Waste Transfers and Miscellaneous Additions, WSRC-TR-93-425, Rev. 0.

11. The tank 41 sample was determined to contain 32 vol\% interstitial supernate. Assuming that the sample was dewatered to some degree in the sampling process, an estimate of $50 \mathrm{vol} \%$ interstitial supernate was chosen as a conservative value for salt interstitial liquid content.

12. In the tank 19 salt removal, the lowest water/salt volume ratio was 1.37 during the first batch. The ratios increased in subsequent batches and an overall ratio of 2.31 was calculated (A. Q. Goslen. Tank 19 Salt Removal. DPSP-84-17-7, (1986), Table 3, p 47). A ratio of 1.00 was chosen to be conservative with respect to uranium dilution.

13. D. T. Hobbs, C. J. Coleman, and R. N. Mahannah. Final Report: Analysis of Tank 41 H Saltcake Sample \#1. WSRC-TR-93-377, Rev 0, (1993).

14. D. T. Hobbs, and C. J. Coleman. Final Report: Analysis of Tank 41 H Salt cake Sample \#2. WSRC-TR-94-057, Rev 0, (1994).

15. G. T Chandler and M. J. Barnes. Evaporation Studies of Simulated Low-Heat and PostAluminum Dissolution Waste. WSRC-RP-94-251, Rev 0, (1994)

16. D. G. Karraker. Uranium Solubility Studies During Waste Evaporation. WSRC-TR-93-433, Rev 0, (1994). 


\author{
Appendix A \\ Temperature Density Effects
}

The density differences between the major categories of waste encountered during tank farm processing can be quite large. The table below shows typical densities for some of the more common types of waste encountered.

\begin{tabular}{lcl} 
Waste Type & $\begin{array}{c}\text { Typical } \\
\text { Specific Gravity }\end{array}$ & Source \\
\cline { 2 - 3 } Salt Dissolution & 1.35 & Reference 12; average Sp Gr of 2nd Tank 19F batch \\
Sludge Removal & 1.18 & DPST-83-668; Tank 15H initial sludge slurry \\
Fresh H-LHW & 1.25 & DPST-82-502; estimated waste density \\
2H Evaporator Bottoms & 1.49 & Typical Tank 41H Sp Gr from dip sample results
\end{tabular}

The density differences most often cited in this report as a basis for mixing scenarios are between materials (such as evaporator bottoms and sludge removal waste) which have differences in specific gravity of around 0.2 units. Published data on the thermal expansion of concentrated salt solutions has been used to calculate the density changes associated with temperature changes which could occur during tank farm processing.

Calculations were made to estimate the density change when concentrated sodium chloride and calcium chloride (solutions were chosen because of readily available thermal expansion data) solutions when the solutions are heated from $20 \mathrm{C}$ to $90 \mathrm{C}$. These temperatures were chosen to simulate a worst case temperature scenario, such as the recycling of hot evaporator concentrate.

The equation used for the thermal expansion of the salt solutions (from Perry's Chemical Engineer's Handbook, 5th Ed., p.3-101, Table 3-149) is of the form:

$$
\mathrm{V}_{\mathrm{t}}=\mathrm{V}_{\mathrm{o}}\left(\mathrm{at}+\mathrm{bt} \mathrm{t}^{2}\right)
$$

Where $V_{t}$ is the volume at temperature $t$ when $V_{0}$ is the volume at $0 \mathrm{C}$. The coefficients a and $b$ were given in Table 3-149 for the salt solutions.

For sodium chloride ( $20.6 \%$ soln.) the coefficient $\mathrm{a}=0.3640 \mathrm{E}-3$ and $\mathrm{b}=1.237 \mathrm{E}-6$.

From published data (CRC Handbook of Chemistry and Physics, 56th Ed., p. D-253) the density of 21\% $\mathrm{NaCl}$ solution at $20 \mathrm{C}$ is $1.1579 \mathrm{~g} / \mathrm{ml}$.

Using equation (1), if the volume at $0 \mathrm{C}$ is $1 \mathrm{ml}$, the volume at $20 \mathrm{C}$ will be $1.00777 \mathrm{ml}$. Multiplying the density by the estimated volume gives a mass of solution of $1.1669 \mathrm{~g}$.

Again using equation (1), if the volume at $0 \mathrm{C}$ is $1 \mathrm{ml}$, the volume at $90 \mathrm{C}$ is $1.04278 \mathrm{ml}$. Dividing this into the mass determined earlier, gives a density at $90 \mathrm{C}$ of $1.1190 \mathrm{~g} / \mathrm{ml}$.

So the density decreases from $1.1579 \mathrm{~g} / \mathrm{ml}$ to $1.1190 \mathrm{~g} / \mathrm{ml}(0.039$ units $)$ as the solution is heated from 20 $\mathrm{C}$ to $90 \mathrm{C}$. 
WSRC-TR-94-0224

Revision 1

\section{Appendix A (Continued) \\ Temperature Density Effects}

For calcium chloride $(40.9 \%$ soln. $)$ the coefficient $a=0.42383 \mathrm{E}-3$ and $b=0.8571 \mathrm{E}-6$.

From published data (CRC Handbook of Chemistry and Physics, 56th Ed., p. D-253) the density of $40 \%$ $\mathrm{CaCl}$ solution at $20 \mathrm{C}$ is $1.3982 \mathrm{~g} / \mathrm{ml}$.

Using equation (1), if the volume at $0 \mathrm{C}$ is $1 \mathrm{ml}$, the volume at $20 \mathrm{C}$ will be $1.00882 \mathrm{ml}$. Multiplying the density by the estimated volume gives a mass of solution of $1.4105 \mathrm{~g}$.

Again using equation (1), if the volume at $0 \mathrm{C}$ is $1 \mathrm{ml}$, the volume at $90 \mathrm{C}$ is $1.04509 \mathrm{ml}$. Dividing this into the mass determined earlier, gives a density at $90 \mathrm{C}$ of $1.3496 \mathrm{~g} / \mathrm{ml}$.

So the density decreases from $1.3982 \mathrm{~g} / \mathrm{ml}$ to $1.3496 \mathrm{~g} / \mathrm{ml}(0.049$ units $)$ as the solution is heated from 20 $\mathrm{C}$ to $90 \mathrm{C}$.

Since the density differences expected from the change in temperature is around four times less than the spread between densities of solutions used in the mixing scenarios, temperature related density changes are considered negligible. 
WSRC-TR-94-0224

Revision 1

\author{
Appendix B \\ Volume Balance Calculations
}

All of the data used to do the volume balances was taken from the Waste Management Monthly Reports. The reports for the period dealt with in this report, had no document number, but were stored as "WMT Monthly Data Report".

The volume balance for Tank $43 \mathrm{H}$ began on 12/31/86 when the level in the tank was reported to be $1,163 \mathrm{kgal}$ with $121 \mathrm{kgal}$ of sludge. The transfer dipleg in Tank $43 \mathrm{H}$ was assumed to be at the $228 \mathrm{kgal}$ level in the tank (from personal communication with J. S. Clemmons), so all the liquid below that level is assumed to be a stagnant heel. The contents of the tank will be represented by the following notation, where $43_{0}$ represents the waste in Tank $43 \mathrm{H}$ on $12 / 31 / 86$.

\title{
121 kgal Sludge / 107 kgal Heel / 935 kgal 43,
}

By $1 / 30 / 87,654 \mathrm{kgal}$ of Tank $41 \mathrm{H}$ recycle and $32 \mathrm{kgal}$ of fresh $\mathrm{H}-\mathrm{LHW}$ had been received in Tank $43 \mathrm{H}$. Since the recycle and the fresh waste had been added intermittently throughout the period, they were assumed to mix and form a layer referred to below as $R F_{1}$. From evaporator operating data, $792 \mathrm{kgal}$ was fed to the evaporator during the month of January, so the daily evaporator feed was assumed to be $792 / 31=25.548 \mathrm{kgal} /$ day. Using this feed rate for the 30 days since the last volume balance was made, gives a total of $766 \mathrm{kgal}$ of $43_{0}$ fed to the evaporator since the last balance. The tank balance notation now looks like this:

\section{2 kgal Sludge / $106 \mathrm{kgal} \mathrm{Heel} \mathrm{/} 169 \mathrm{kgal} 43_{0} / 685 \mathrm{kgal} \mathrm{RF} 1$}

The Tank $43 \mathrm{H}$ volume balance was carried out in this same manner until the $2 \mathrm{H}$ Evaporator stopped feeding bottoms to Tank $41 \mathrm{H}$. From these balances estimated were made concerning the origin of the material which was being fed to the $2 \mathrm{H}$ Evaporator. 


\section{Appendix C \\ Uranium Content Sample Calculation}

The three components which were assumed to make up the hypothetical layer L2 were $18 \mathrm{kgal}$ of H-LHW, $249 \mathrm{kgal}$ of Tank $41 \mathrm{H}$ recycle, and $131 \mathrm{kgal}$ of waste from Tank $51 \mathrm{H}$.

The uranium concentration of the mixture was calculated as follows:

Total volume $=18 \mathrm{kgal}+249 \mathrm{kgal}+131 \mathrm{kgal}=398 \mathrm{kgal}$ total L2 volume $(1,504$ kiloliters $)$

The concentration of $U$ in the recycle was assumed to be $22 \mathrm{mgU} / \mathrm{L}$, so the mass of $U$ in the recycle is: $249,000 \mathrm{gal} \times 3.78 \mathrm{~L} / \mathrm{gal} \times 22 \mathrm{mgU} / \mathrm{L}=20,706,840 \mathrm{mgU}$ from recycle.

The concentration of $U$ in the Tank $51 \mathrm{H}$ waste was assumed to be $10 \mathrm{mgU} / \mathrm{L}$, so the mass of $U$ in the recycle is:

$131,000 \mathrm{gal} \times 3.78 \mathrm{~L} / \mathrm{gal} \times 10 \mathrm{mgU} / \mathrm{L}=4,951,800 \mathrm{mgU}$ from Tank $51 \mathrm{H}$.

The fresh H-LHW was assumed to contain no U.

Dividing the total $\mathrm{U}$ added by the final volume gives the bulk uranium concentration of the $\mathrm{L} 2$ mixture. $(20,706,840 \mathrm{mgU}$ from recycle $+4,951,800 \mathrm{mgU}$ from Tank $51 \mathrm{H}) / 1,504,000 \mathrm{~L}=17 \mathrm{mg} \mathrm{U} / \mathrm{L}$

The U-235 enrichment of the mixture was calculated as follows:

The U-235 enrichment of the recycle material was assume to be $22 \%$, and the enrichment of the Tank $51 \mathrm{H}$ waste was assumed to be $5 \%$.

The mass of $\mathrm{U}-235$ in the recycle material was:

$20,706,840 \mathrm{mgU}$ from recycle $\mathrm{x} 0.22=4,555,505 \mathrm{mg} \mathrm{U}-235$ from recycle

The mass of U-235 in the Tank $51 \mathrm{H}$ material was:

$4,951,800 \mathrm{mgU}$ from Tank $51 \mathrm{H} \times 0.05=247,590 \mathrm{mg} \mathrm{U}-235$ from Tank $51 \mathrm{H}$

The L2 enrichment was calculated as follows:

$4,555,505 \mathrm{mg}$ U-235 from recycle $+247,590 \mathrm{mg} \mathrm{U}-235$ from Tank $51 \mathrm{H} \times 100=19 \%$ Enriched in U-235 $20,706,840 \mathrm{mgU}$ from recycle $+4,951,800 \mathrm{mgU}$ from Tank $51 \mathrm{H}$ 